\title{
Changes in food advertisements during 'prime-time' television from 1991 to 2006 in the UK and Canada
}

\author{
Jean Adams ${ }^{1}$, Kathleen Hennessy-Priest ${ }^{2}$, Sigrún Ingimarsdóttir ${ }^{1}$, Judy Sheeshka ${ }^{2}$, Truls Østbye ${ }^{3}$ \\ and Martin White ${ }^{1}$ \\ ${ }^{1}$ Institute of Health and Society, William Leech Building, Newcastle University, Newcastle upon Tyne NE2 4HH, UK \\ ${ }^{2}$ Department of Family Relations and Applied Nutrition, University of Guelph, Guelph, ON, Canada, N1G 2W1 \\ ${ }^{3}$ Department of Community and Family Medicine, Duke University School of Medicine, Box 2914, Durham, NC 27710, USA
}

(Received 23 June 2008 - Revised 11 November 2008 - Accepted 4 December 2008 - First published online 25 February 2009)

Food advertisements on mainstream television have received less research attention than those on children's television. Little is known about how television food advertisements vary internationally or if there have been changes over recent years. We describe food-related television advertisements and the nutrient content of foods advertised during prime-time television in Ontario, Canada and the UK in 1991 and 2006. Information on what advertisements were broadcast were obtained from video recordings and audience research bureaux. Data on nutrient content of foods advertised were obtained from manufacturers and standard food tables. The proportion of advertisements that were food related decreased between 1991 and 2006 in both countries. The frequency of food-related advertisements was relatively constant in Canada but decreased between 1991 and 2006 in the UK. In 1991, advertisements for beverages and meals predominated in both countries. By 2006, food-related advertisements in Canada were dominated by meals and restaurants. In the UK advisements for food stores and beverages predominated. The 'TV diet' in Canada in 1991 was relatively high in fat, high in alcohol and low in fibre, compared to current recommendations. By 2006, this had changed to high in fat and sodium and low in fibre. The 'TV diet' in the UK in 1991 was high in fat, sodium, sugar and alcohol and low in fibre compared to current recommendations. By 2006, the UK 'TV diet' was high in sodium, sugar and alcohol and low in fibre. Foods advertised on 'prime-time' television do not reflect a healthful diet.

Media: Broadcasting: Diet: Marketing: Commercials

Overweight and obesity are now recognised as worldwide public health problems that increase risk of a number of chronic diseases ${ }^{(1)}$. A positive relationship between time spent watching television and body weight has been consistently documented ${ }^{(2-4)}$. Compounding the fact that television watching is a sedentary activity, advertisements for foods high in fat, salt and sugar are common on television, encouraging unhealthy food choices amongst viewers ${ }^{(5)}$. Advertising clearly has the potential to influence individuals' preferences and behaviours and the near ubiquity of food advertisements, alongside their potential impact on diet and body weight, has led to increasing demands for regulation, particularly on children's television ${ }^{(6-11)}$.

A 2003 systematic review of the effects of food promotion on children concluded that whilst 'with this kind of research, incontrovertible proof simply isn't attainable ... the literature does suggest food promotion is influencing children's diet in a number of ways ${ }^{(5)}$. In particular, television food advertising appears to influence children's food preferences and purchasing behaviour ${ }^{(12)}$. Although potentially modest, these effects appear to be both independent of other effects, and occurring at the product as well as category level. Thus, children exposed to food advertisements are more likely to choose the advertised product but also to express a general preference for less healthy foods ${ }^{(5)}$. Children who are exposed to more adverts and are more attentive to them also appear to make more purchasing requests to parents: so-called 'pester power' ${ }^{(5)}$. In addition, there is potential for wider, indirect effects of television advertising of advertised foods, in terms of normalising such products and making them more salient to consumers ${ }^{(13)}$. Television food advertising, therefore, has the potential to influence the development of overweight, obesity and related conditions in otherwise healthy children ${ }^{(12)}$. The impact of television food advertising on adults is less well documented but, given the amount of food advertising revenue spent (television food advertising spend in the $\mathrm{UK}$ is in the hundreds of millions of pounds $\left.{ }^{(14)}\right)$, is unlikely to be negligible.

Numerous content analyses have documented food advertising on television ${ }^{(5,15-21)}$. Whilst broad food categories are often described, detailed data on the specific nutritional content of television food advertisements are less commonly published $^{(5)}$ and the methods used by those studies that do document nutritional content vary widely ${ }^{(22-24)}$. Furthermore, almost all previous analyses have focused on children's television, either by restricting analysis to specific children's 
channels, programmes or time periods ${ }^{(17-19,25-28)}$ or using viewing figures to identify those programmes most popular with children $^{(22,23)}$. There has been little focus on the wider television advertising landscape as watched by adults, as well as children ${ }^{(27,29-31)}$. Thus, despite evidence that television food advertising affects children's food preferences and behaviour and the strong possibility that this effect extends to adults, there is currently little detailed data available on the exact nutritional content of the foods that are being advertised on mainstream television, particularly outside of the USA.

Although some data on international variations in the frequency of television food advertisements has been published $^{(32)}$, it is not clear if there are important international differences in the nutritional content of foods advertised on television. Nor has substantial data been published on changes in television food advertising over time. Health promoters, consumer groups and politicians in many developed countries are now calling for increased regulation of TV food advertising $^{(6-11,33-37)}$ and industry may respond with increased selfregulation $^{(38)}$. Whilst there is evidence from both the USA and Australia that the proportion of all television advertisements that are for food has decreased over time ${ }^{(39-41)}$, and from Australia that the proportion of food advertisements that are for 'unhealthy' foods also decreased over time ${ }^{(40,41)}$, time trends in other countries have not been documented.

In order to fill some of these gaps, we analysed food-related advertisements, and the nutrient content of advertised foods, during 'prime-time' television in Canada and the UK in 1991 and 2006.

\section{Methods}

The present study built on previous work on television food advertising in Canada in $1991^{(15)}$ using the same methods, as far as possible.

\section{Channels and times of interest}

In 1991 five channels broadcast in Ontario, Canada, that represented $65 \%$ of 'prime-time' viewership, were studied: CBC (English), CBC (French), CTV, CFPL and Much Music. The equivalent, free-to-view, channels included in 2006 were CBC (Toronto), SRC (Montreal), CTV (Toronto) and A-channel (a re-branding of CFPL). Much Music was no longer free-to-view in 2006. In the UK all commercial terrestrial channels were included in both years: ITV and Channel 4 in 1991, supplemented by Channel 5 in 2006. Terrestrial channels in the UK are those that are free-toview and do not require specialist receiver equipment. In 1991, commercial terrestrial channels in the UK accounted for $52 \%$ of viewing, falling to $35 \%$ in 2006 as more digital and cable channels became available ${ }^{(42)}$.

All advertisements broadcast during prime-time in the week beginning the last Monday of October were studied in both years (26 October to 1 November 1991; 30 October to 5 November 2006). This represented a typical week, not too close to season premieres or the holiday season. As previously, prime-time was defined as $19.00-22.59$ hours $^{(15,39)}$, giving a total of $28 \mathrm{~h}$ of programming per channel per country per year.

\section{Advertisements broadcast}

Information on all advertisements broadcast during the times of interest in Canada in 1991 was obtained by video-recording the study channels. In all other cases, data were purchased from audience research bureaux: the British Audience Research Board (BARB) for UK data in 1991, Attentional Ltd for UK data in 2006, and BBM Analytics for Canadian data in 2006. With the exception of BARB (which is funded directly by broadcasters), these bureaux are commercial organisations that supply data to broadcasters, manufacturers and advertisers to help them plan and evaluate their broadcast strategies.

For each advertisement, the main product or brand range promoted was recorded. As we did not have access to the actual advertisements broadcast in the majority of cases, we did not have information on what other products may have been shown incidentally in advertisements, or the creative techniques used to promote products.

\section{Categorical analysis of food-related advertisements}

All advertisements for food and food retailers (food stores and restaurants) were identified. These are termed 'food-related advertisements' and were categorised using a schema of categories and sub-categories based on the groupings used in the Canadian Nutrition Recommendations (see Table 1) ${ }^{(43,44)}$. In this schema, advertisements for specific fast-food products (e.g. McDonald's Big Mac or Happy Club Meal) were categorised as 'Meals: hamburgers \& fast food'

Table 1. Summary of hours of programming studied and number, proportion and frequency of food-related advertisements $†$

\begin{tabular}{|c|c|c|c|c|c|}
\hline \multirow[b]{2}{*}{ Variable of interest } & \multicolumn{2}{|c|}{ Canada } & \multicolumn{2}{|c|}{ UK } & \multirow[b]{2}{*}{ Total } \\
\hline & 1991 & 2006 & 1991 & 2006 & \\
\hline No. of channels & 5 & 4 & 2 & 3 & \\
\hline Hours of programming & 140 & 112 & 56 & 84 & 392 \\
\hline Total no. of adverts & 2448 & 3738 & 871 & 1872 & 8929 \\
\hline No. of food-related adverts & 679 & 570 & 290 & 318 & 1857 \\
\hline Food-related adverts as $\%$ of all adverts & $27 \cdot 7$ & $15 \cdot 2$ & $33 \cdot 3$ & $17 \cdot 0$ & $20 \cdot 8$ \\
\hline Frequency of all adverts per $h$ & 17.5 & 33.4 & $15 \cdot 6$ & $22 \cdot 3$ & $22 \cdot 8$ \\
\hline Frequency of food-related adverts per $\mathrm{h}$ & 4.9 & $5 \cdot 1$ & $5 \cdot 2$ & 3.8 & 4.7 \\
\hline
\end{tabular}

†For details of procedures, see Methods. 
whilst advertisements for fast-food chains that did not mention specific products were categorised as 'Restaurants: fast food'.

Variations in the proportion of food advertisements that fell into each main category between years in each country, and between countries in each year, were assessed using the $\chi^{2}$ test of difference in proportion with Yates' correction or Fisher's exact test where appropriate. Within- and betweencountry comparisons were not performed for sub-categories in order to avoid multiple comparisons.

\section{Nutritional analysis of food advertisements and estimation of the ' $T V$ diet'}

The sub-group of food-related advertisements for specific foods (e.g. excluding those advertisements for food stores and restaurants) were then subject to a nutritional analysis. For each food advertisement, the energy, protein, carbohydrate, sugar, fat, alcohol, fibre and sodium content of the main product advertised was determined. This was done using computer software in 1991 (Nutritionist III from N-Square Computing, 1985 (Canada) and Microdiet (UK)), supplemented by manufacturers' data displayed on packaging where necessary. In 2006, product-specific data displayed on packaging and manufacturers' websites was used as far as possible, supplemented with standard food table data where necessary ${ }^{(45,46)}$. The sodium content of foods advertised in Canada in 1991 was not available.

For advertisements for brand ranges, rather than specific products (e.g. Fox's Biscuits, rather than Fox's Classic), a single 'default' product was identified and the nutritional content for that product was used in analyses. The choice of 'default' products was based on the authors' consensus judgement of the most popular products within brand ranges.

In order to summarise the nutritional content of foods advertised, we used the concept of the 'TV diet ${ }^{\text {'(27) }}$. To determine the composition of the 'TV diet', each advertisement broadcast was assumed to represent one portion of the product advertised, with portion sizes determined from standard tables $^{(47)}$ for Canadian products in 1991 and package sizes or information displayed on packages in all other cases. The total percentage of energy from each macronutrient, as well as dietary fibre and sodium density (in $\mathrm{g} / 1000 \mathrm{~kJ}$ ) for all foods advertised was then calculated.

Information on the reported diets of Canadian and British adults in 1991 and 2006 were obtained from large, national nutritional surveys and, in the case of sugar and alcohol consumption by Canadians in 2006 where recent data is not available, estimates from available food and energy in the national food supply, adjusted for losses ${ }^{(42,48-50)}$. The nutrient content of advertised foods was compared both to these reported diets and to recommended nutritional guidelines published by the Canadian and UK governments current in $2006^{(44,51-53)}$.

\section{Results}

A total of 8929 advertisements broadcast over $392 \mathrm{~h}$ of programming were analysed (see Table 1). Of these, 1857 $(20.8 \%)$ advertisements were for food-related products, an average of 4.7 food-related advertisements per hour of programming. In 1991, the frequency of food-related advertisements was approximately the same in Canada (4.9/h) and the UK (5·2/h). Between 1991 and 2006 in both Canada and the UK, the proportion of all advertisements that were foodrelated decreased and the frequency of advertisements in general increased. Whilst in Canada this led to a similar frequency of food-related advertisements in both 1991 (4.9/h) and 2006 $(5 \cdot 1 / \mathrm{h})$, in the UK there was a decrease in the frequency of food-related advertisements between 1991 (5.2/hour) and 2006 (3·8/hour).

\section{Categorical analysis of food-related advertisements}

The number and proportion of food-related advertisements that fell into each category and sub-category, with the results of within- and between-country tests of difference in proportion across main categories only, are shown in Table 2.

The most common categories of food-related advertisements in both countries in 1991 were beverages $(21.6 \%$ of food advertisements in Canada; $19.3 \%$ in the UK) and meals (16.1\% in Canada; $22.1 \%$ in the UK). By 2006, these had changed to meals $(29.5 \%)$ and restaurants $(15.6 \%)$ in Canada, and food stores $(30.5 \%)$ and beverages $(22.3 \%)$ in the UK. The proportion of advertisements for food stores increased more than six-fold between 1991 and 2006 in the UK (from 4.5 to $30.5 \%$ ), but advertisements for food stores were relatively uncommon in Canada in both years $5.0 \%$ in $1991 ; 5.8 \%$ in 2006). Similarly, there was more than a sixfold increase in the proportion of food-related advertisements that were for restaurants from 1991 to 2006 in Canada (from 2.4 to $15.6 \%$ ), but there were no advertisements for restaurants in either year in the UK.

In 1991, a significantly higher proportion of food-related advertisements were for fruits, vegetables and juices in Canada compared with the UK $\left(8.0 \%\right.$ v. $1.0 \%, \chi^{2}=17.6$, $P<0.001$ ), and a significantly lower proportion for sweets and candy $\left(7.2 \%\right.$ v. $\left.14.1 \%, \chi^{2}=11.6, P<0 \cdot 001\right)$. By 2006 the first of these trends had reversed $(1.6 \%$ in Canada, $7.2 \%$ in the UK, $\left.\chi^{2}=18 \cdot 8, P<0.001\right)$ and the proportion of advertisements for sweets and candy in the UK decreased to the degree that, by 2006 , there was no difference between the countries $(6.3 \%$ in Canada, $6.6 \%$ in the UK).

Overall, twenty-eight $(4 \cdot 1 \%)$ advertisements were for fastfood products or restaurants in Canada in 1991. This increased substantially to $141(24.7 \%)$ in 2006. In the UK, twelve (4.1\%) advertisements were for fast-food products or restaurants in 1991, increasing less rapidly than in Canada, to thirty-three $(10.4 \%)$ in 2006

Substantial between-channel heterogeneity in the proportion of food-related advertisements in many categories was seen in the earlier Canadian sample ${ }^{(15)}$ and this was partially followed through to 2006 (data not shown). In contrast, little betweenchannel heterogeneity was seen in the UK in either year.

\section{Nutritional analysis of food advertisements and estimation of the 'TV diet'}

The nutritional content of all foods advertised (the 'TV diet') during the periods of interest is summarised in Table 3. In both 1991 and 2006, the percentage of energy derived from protein, carbohydrate and sugar in the Canadian TV diet were all within 2006 recommended ranges. However, in both years the fibre content of the Canadian TV diet was 
Table 2. Food and food-related advertisements in 1991 and 2006 in Canada and UK by food category $†$

\begin{tabular}{|c|c|c|c|c|c|c|c|c|c|c|c|c|}
\hline \multirow[b]{3}{*}{ Food category (sub-categories) } & \multicolumn{5}{|c|}{ Canada } & \multicolumn{5}{|c|}{ UK } & \multicolumn{2}{|c|}{ Canada v. UK } \\
\hline & \multicolumn{2}{|c|}{1991} & \multicolumn{2}{|c|}{2006} & \multirow[b]{2}{*}{1991 v. 2006, $\chi^{2}$ (1 df) } & \multicolumn{2}{|c|}{1991} & \multicolumn{2}{|c|}{2006} & \multirow[b]{2}{*}{1991 v. 2006, $\chi^{2}$ (1 df) } & \multirow[b]{2}{*}{$1991, \chi^{2}(1 \mathrm{df})$} & \multirow[b]{2}{*}{ 2006, $\chi^{2}(1 \mathrm{df})$} \\
\hline & $n$ & $\%$ & $n$ & $\%$ & & $n$ & $\%$ & $n$ & $\%$ & & & \\
\hline Beverages & 147 & $21 \cdot 6$ & 65 & 11.4 & $23 \cdot 1^{\star \star \star}$ & 56 & $19 \cdot 3$ & 71 & $22 \cdot 3$ & 0.8 & 0.7 & $18 \cdot 8^{\star \star \star}$ \\
\hline Soda (regular) & 34 & $5 \cdot 0$ & 1 & 0.2 & - & 4 & 1.4 & 0 & 0 & - & - & - \\
\hline Soda (sugar-free) & 15 & $2 \cdot 2$ & 0 & 0 & - & 0 & 0 & 13 & $4 \cdot 1$ & - & - & - \\
\hline Water, flavoured & 0 & 0 & 2 & 0.4 & - & 0 & 0 & 0 & 0 & - & - & - \\
\hline High-energy drinks & 0 & 0 & 4 & 0.7 & - & 0 & 0 & 0 & 0 & - & - & - \\
\hline Beer (regular) and wine & 81 & 11.9 & 31 & 5.4 & - & 32 & 11.0 & 8 & 2.5 & - & - & - \\
\hline Cider & 0 & 0 & 0 & 0 & - & 5 & 1.7 & 11 & 3.5 & - & - & - \\
\hline Beer (light) & 0 & 0 & 9 & 1.6 & - & 0 & 0 & 0 & 0 & - & - & - \\
\hline Spirits and liqueurs & 0 & 0 & 5 & 0.9 & - & 2 & 0.7 & 14 & 4.4 & - & - & - \\
\hline Coffee and tea & 17 & 2.5 & 13 & $2 \cdot 3$ & - & 13 & 4.5 & 25 & 7.9 & - & - & - \\
\hline Milk and milk products & 36 & $5 \cdot 3$ & 78 & 13.7 & $26 \cdot 3^{\star \star \star}$ & 15 & $5 \cdot 2$ & 7 & $2 \cdot 2$ & $3 \cdot 8^{*}$ & 0.01 & $31 \cdot 1^{\star \star \star}$ \\
\hline Milk & 6 & 0.9 & 20 & 3.5 & - & 7 & $2 \cdot 4$ & 3 & 0.9 & - & - & - \\
\hline Yoghurt & 2 & 0.3 & 8 & 1.4 & - & 4 & 1.4 & 0 & 0 & - & - & - \\
\hline Cheese & 23 & 3.4 & 41 & $7 \cdot 2$ & - & 4 & 1.4 & 0 & 0 & - & - & - \\
\hline Other milk products & 5 & 0.7 & 9 & 1.6 & - & 0 & 0 & 4 & 1.3 & - & - & - \\
\hline Fruits, vegetables and juices & 54 & $8 \cdot 0$ & 9 & 1.6 & $26 \cdot 3^{\star \star \star}$ & 3 & 1.0 & 23 & $7 \cdot 2$ & $14 \cdot 2^{\star \star \star}$ & $17 \cdot 6^{\star \star *}$ & $18 \cdot 8^{\star \star \star}$ \\
\hline Fruit and vegetable juices & 21 & $3 \cdot 1$ & 7 & 1.2 & - & 1 & 0.3 & 8 & 2.5 & - & - & - \\
\hline Fruit & 2 & 0.3 & 1 & 0.2 & - & 0 & 0 & 10 & $3 \cdot 1$ & - & - & - \\
\hline French fries & 31 & 4.6 & 1 & 0.2 & - & 1 & 0.3 & 5 & 1.6 & - & - & - \\
\hline Other potato products & 0 & 0 & 0 & 0 & - & 1 & 0.3 & 0 & 0 & - & - & - \\
\hline Salty snacks & 11 & 1.6 & 2 & 0.4 & 3.7 & 8 & $2 \cdot 8$ & 0 & 0 & $6 \cdot 9^{* *}$ & 1.4 & 0.1 \\
\hline Grain products & 77 & 11.3 & 65 & 11.4 & 0 & 40 & $13 \cdot 8$ & 29 & $9 \cdot 1$ & $3 \cdot 3$ & $1 \cdot 2$ & $1 \cdot 1$ \\
\hline Breakfast cereals & 49 & $7 \cdot 2$ & 43 & 7.5 & - & 28 & 9.7 & 18 & $5 \cdot 7$ & - & - & - \\
\hline Breakfast cereal bars & 0 & 0 & 9 & 1.6 & - & 0 & 0 & 0 & 0 & - & - & - \\
\hline Other grain products & 28 & $4 \cdot 1$ & 13 & $2 \cdot 3$ & - & 12 & $4 \cdot 1$ & 11 & 3.5 & - & - & - \\
\hline Meat and alternatives & 37 & $5 \cdot 4$ & 7 & 1.2 & $16 \cdot 3^{\star \star \star}$ & 11 & 3.8 & 1 & 0.3 & $9 \cdot 5^{\star \star}$ & 1.2 & 1.0 \\
\hline Meat & 18 & $2 \cdot 7$ & 0 & 0 & - & 3 & 1.0 & 0 & 0 & - & - & - \\
\hline Eggs & 5 & 0.7 & 2 & 0.4 & - & 0 & 0 & 0 & 0 & - & - & - \\
\hline Chicken and turkey & 14 & $2 \cdot 1$ & 3 & 0.5 & - & 8 & $2 \cdot 8$ & 0 & 0 & - & - & - \\
\hline Fish & 0 & 0 & 2 & 0.4 & - & 0 & 0 & 1 & 0.3 & - & - & - \\
\hline Butter, margarine and spreads & 43 & $6 \cdot 3$ & 0 & 0 & $35 \cdot 5^{\star \star \star}$ & 13 & 4.5 & 4 & 1.3 & $5 \cdot 8^{*}$ & 1.3 & $4 \cdot 6^{\star}$ \\
\hline Sweets and candy & 49 & $7 \cdot 2$ & 36 & $6 \cdot 3$ & 0.4 & 41 & $14 \cdot 1$ & 21 & $6 \cdot 6$ & $9 \cdot 4^{\star *}$ & $11 \cdot 6^{\star \star \star}$ & 0.03 \\
\hline Chewing gum & 21 & $3 \cdot 1$ & 7 & 1.2 & $4.9^{*}$ & 4 & 1.4 & 0 & 0 & $2 \cdot 6$ & $2 \cdot 4$ & 2.5 \\
\hline Miscellaneous & 45 & 6.6 & 11 & 1.9 & $16 \cdot 0^{* \star \star}$ & 22 & 7.6 & 19 & $6 \cdot 0$ & 0.6 & 0.3 & $10 \cdot 2^{\star * *}$ \\
\hline Meals & 109 & $16 \cdot 1$ & 168 & 29.5 & $32 \cdot 3^{\star \star \star}$ & 64 & $22 \cdot 1$ & 46 & 14.5 & $5 \cdot 9^{*}$ & $5 \cdot 0^{*}$ & $25 \cdot 1^{\star \star \star}$ \\
\hline Hamburgers and fast food & 25 & $3 \cdot 7$ & 127 & $22 \cdot 3$ & - & 12 & $4 \cdot 1$ & 33 & $10 \cdot 4$ & - & - & - \\
\hline Meal substitute and diet bars & 17 & 2.5 & 1 & 0.2 & - & 1 & 0.3 & 0 & 0 & - & - & - \\
\hline Other meals & 67 & 9.9 & 40 & 7 & - & 51 & $17 \cdot 6$ & 13 & $4 \cdot 1$ & - & - & - \\
\hline Restaurants & 16 & $2 \cdot 4$ & 89 & $15 \cdot 6$ & $70 \cdot 7^{\star *}$ & 0 & 0 & 0 & 0 & 0 & $5 \cdot 6^{*}$ & $53 \cdot 5^{\star \star *}$ \\
\hline Fast food & 3 & 0.5 & 14 & 2.5 & - & 0 & 0 & 0 & 0 & - & - & - \\
\hline Traditional & 13 & 1.9 & 75 & $13 \cdot 2$ & - & 0 & 0 & 0 & 0 & - & - & - \\
\hline Food stores & 34 & $5 \cdot 0$ & 33 & 5.8 & 0.4 & 13 & 4.5 & 97 & 30.5 & $69 \cdot 3^{\star \star *}$ & 0.1 & $99 \cdot 8^{\star \star \star}$ \\
\hline Total no. of food-related adverts & 679 & 100 & 570 & 100 & & 290 & 100 & 318 & 100 & & & \\
\hline All adverts (\% food) & 2448 & $27 \cdot 7$ & 3738 & $15 \cdot 2$ & $143 \cdot 7^{\star \star *}$ & 871 & 33.3 & 1872 & $17 \cdot 0$ & $91 \cdot 6^{\star \star \star}$ & $9 \cdot 8^{* *}$ & 3.0 \\
\hline
\end{tabular}

, Within- and between-country differences not calculated for sub-categories in order to avoid multiple comparisons. 
Table 3. Nutritional content of foods advertised in 1991 and 2006 in Canada and the UK, with contemporaneous actual and recommended dietary intakes $†$

\begin{tabular}{|c|c|c|c|c|c|c|c|c|c|c|}
\hline \multirow[b]{2}{*}{ Nutrient } & \multicolumn{5}{|c|}{ Canada } & \multicolumn{5}{|c|}{ UK } \\
\hline & $\begin{array}{l}\text { Advertised foods, } \\
1991 \text { ( } n \text { 629) }\end{array}$ & $\begin{array}{l}\text { Reported diet, } \\
1991^{(43)}\end{array}$ & $\begin{array}{l}\text { Advertised } \\
\text { foods, 2006 } \\
(n 448)\end{array}$ & $\begin{array}{l}\text { Reported diet, } \\
2006^{(48,49)}\end{array}$ & $\begin{array}{l}\text { Recommended } \\
\operatorname{diet}^{(44,52,53)}\end{array}$ & $\begin{array}{l}\text { Advertised } \\
\text { foods, 1991 } \\
(n 277)\end{array}$ & $\begin{array}{l}\text { Reported diet, } \\
1991^{(50)} \ddagger\end{array}$ & $\begin{array}{l}\text { Advertised } \\
\text { foods, 2006 } \\
(n 221)\end{array}$ & $\begin{array}{l}\text { Reported diet, } \\
2006^{(50)} \S\end{array}$ & $\begin{array}{l}\text { Recommended } \\
\operatorname{diet}^{(51)} \|\end{array}$ \\
\hline Protein (\% energy) & 12 & 15 & $14 \cdot 1$ & $16 \cdot 5$ & $10-35$ & 11.5 & $14 \cdot 7$ & $12 \cdot 8$ & $15 \cdot 7$ & 9 \\
\hline $\begin{array}{l}\text { Carbohydrate } \\
\text { (\% energy) }\end{array}$ & 46 & 48 & $47 \cdot 1$ & $49 \cdot 1$ & $45-65$ & 40.9 & $42 \cdot 3$ & 45.9 & $45 \cdot 7$ & 50 \\
\hline Sugar (\% energy) & 17 & - & $18 \cdot 5$ & $10 \cdot 4 q$ & $\leq 25$ & 13.3 & - & $15 \cdot 5$ & $12 \cdot 8$ & 11 \\
\hline Fibre ( $g / 1000 \mathrm{~kJ})$ & 1.0 & $1.4-1.9$ & 1.2 & $2 \cdot 0$ & $3.0 \S \S$ & 0.8 & - & 1.3 & 1.3 & $4 \cdot 3$ \\
\hline Fat (\% energy) & 34 & 38 & $36 \cdot 6$ & $31 \cdot 3$ & $20-35$ & 44.7 & 38.4 & 32.5 & 33.5 & 35 \\
\hline Alcohol (\% energy) & 7 & $5-8$ & 3 & $6.4+\dagger$ & $\leq 5$ & 7.5 & 4.9 & $6 \cdot 6$ & $5 \cdot 2$ & 6 \\
\hline Sodium (g/1000 kJ) & - & - & 0.4 & $0.3 \ddagger \ddagger$ & $0.2 \ddagger \ddagger,\|\| \|$ & 0.5 & - & 0.4 & 0.399 & 0.2 ๆ \\
\hline
\end{tabular}

-, Data not available.

$\dagger$ For details of procedures, see Methods.

$\ddagger$ Average of the average intake for men and women, aged 16-64, Dietary and Nutrition Survey of British Adults, 1986/7.

§ Average of the average intake for men and women, age 19-64, National Diet and Nutrition Survey, 2000/1 and, in the case of nutrients measured in g/1000 kJ, an assumed daily energy intake of $10460 \mathrm{~kJ}$.

$\|$ Average of the reference nutrient intake for adult men and adult women and, in the case of nutrients measured in $\mathrm{g} / 1000 \mathrm{~kJ}$, an assumed daily energy intake of $10460 \mathrm{~kJ}$.

1 Calculated from total available sugars and syrups, and total available energy per person per year (adjusted for losses) in 2006.

††Calculated from an assumed daily energy intake of $10460 \mathrm{~kJ} / \mathrm{d}$.

$\S \S$ Average of the recommended adequate intake for adult men and adult women and assumed daily energy intake of $10460 \mathrm{~kJ}$.

IIII Tolerable upper level of daily sodium intake.

Tी From www.salt.co.uk

ily sodium intake. 
substantially lower than recommended $(1.0 \mathrm{~g} / 1000 \mathrm{~kJ}$ in 1991 and $1.2 \mathrm{~g} / 1000 \mathrm{~kJ}$ in 2006 , compared to recommendation of $3.0 \mathrm{~g} / 1000 \mathrm{~kJ})$. In 1991 , the percentage of energy derived from alcohol in the Canadian TV diet was higher than recommended but this reduced to within recommended ranges by 2006 (7\% in 1991, $3 \%$ in 2006, compared to recommendation of $\leq 5 \%$ ). A small increase in the percentage of energy derived from fat in the Canadian TV diet between 1991 and 2006 meant that this was higher than recommended in 2006 (34\% in $1991,36.6 \%$ in 2006 , compared to recommendation of $20-35 \%$ ). The sodium content of the Canadian TV diet in 1991 was not available, but in 2006 it was twice recommended limits $(0.4 \mathrm{~g} / 1000 \mathrm{~kJ}$, compared to recommendation of $0.2 \mathrm{~g} / 1000 \mathrm{~kJ}$ ).

The TV diet in the UK differed more from recommendations than that in Canada. The percentage of energy derived from protein in the UK TV diet was higher in both 1991 and 2006 than recommended $(11.5 \%$ in $1991,12.8 \%$ in 2006, compared to recommendation of $9 \%$ ). The percentage of energy derived from carbohydrate was lower in both years than recommended (40.9\% in $1991,45.9 \%$ in 2006 , compared to recommendation of $50 \%$ ). The percentage of energy derived from sugar and alcohol was higher in the UK TV diet in both 1991 and 2006 compared to recommendations (sugar $13.3 \%$ in $1991,15.5 \%$ in 2006 , compared to recommendation of $11 \%$; alcohol $7.5 \%$ in $1991,6.6 \%$ in 2006 , compared to recommendation of $6 \%$ ). Furthermore, in both years the fibre content of the UK TV diet was lower than recommended and the sodium content higher than recommended (fibre $0.8 \mathrm{~g} / 1000 \mathrm{~kJ}$ in $1991,1.3 \mathrm{~g} / 1000 \mathrm{~kJ}$ in 2006 , compared to recommendation of $4.3 \mathrm{~g} / 1000 \mathrm{~kJ}$; sodium $0.5 \mathrm{~g} / 1000 \mathrm{~kJ}$ in $1991,0.4 \mathrm{~g} / 1000 \mathrm{~kJ}$ in 2006 , compared to recommendation of $0.2 \mathrm{~g} / 1000 \mathrm{~kJ}$ ).

The most notable differences in the Canadian TV diet in 1991 compared to the reported diet of Canadians in 1991 was a substantially lower fibre content $(1.0 \quad v .1 .4-1.9 \mathrm{~g} /$ $1000 \mathrm{~kJ})$, a lower percentage of energy derived from protein (12 v. $15 \%)$ and a lower percentage of energy derived from fat $(34 v .36 \cdot 6 \%)$. In 2006 , there remained a substantially lower fibre content in the Canadian TV diet, compared to the reported diet of Canadians $(1.2 v$. $2.0 \mathrm{~g} / 1000 \mathrm{~kJ})$. In addition, compared to the reported diet of Canadians, the Canadian TV diet in 2006 had a much greater percentage of energy derived from sugar $(18.5 v .10 .4 \%)$ and a greater sodium content $(0.4 v .0 .2 \mathrm{~g} / 1000 \mathrm{~kJ})$.

Compared to the reported diet in the UK in 1991, the 1991 UK TV diet was noticeably higher in percentage of energy derived from alcohol $(7.5$ v. $4.9 \%)$ and fat (44.7 v. 38.4\%), but the percentage of energy derived from protein was markedly lower $(11.5$ v. $14.7 \%)$. By 2006, the UK TV diet differed most from reported diets in terms of sodium content $(0.4$ v. $0.3 \mathrm{~g} / 1000 \mathrm{~kJ})$ and percentage of energy derived from alcohol $(6 \cdot 6$ v. $5 \cdot 2 \%)$ and sugar $(15 v .12 \cdot 8 \%)$.

The most striking differences seen between the Canadian TV diet in 1991 and 2006 was a large drop in the percentage of energy derived from alcohol (from 7 to $6.4 \%$ ) and an increase in fibre density (from 1.0 to $1.2 \mathrm{~g} / 1000 \mathrm{~kJ}$ ). There was also a marked increase in the percentage of energy derived from protein (from 12 to $14 \cdot 1 \%$ ). The most marked differences between the UK TV diets in 1991 and 2006 were decreases in the percentage of energy derived from fat (from 44.7 to $32.5 \%$ ) and sodium density (from 0.5 to $0.4 \mathrm{~g}$ / $1000 \mathrm{~kJ}$ ) and a large increase in the fibre density of advertised foods (from 0.8 to $1.3 \mathrm{~g} / 1000 \mathrm{~kJ}$ ).

Comparing the TV diet in the UK in 1991 to that in Canada, the largest differences were a greater percentage of energy derived from fat $(44.7$ v. $34 \%)$, a lower percentage of energy derived from sugar $(13.3 v .17 \%)$, and a lower fibre content $(0.8$ v. $1.0 \mathrm{~g} / 1000 \mathrm{~kJ})$ in the UK compared to Canada. In 2006, the most noticeable differences when comparing the UK to Canadian TV diet were a much greater percentage of energy derived from alcohol (6.6 v. $3 \%)$, and a lower percentage of energy derived from sugar $(15.5$ v. $18.5 \%)$ and fat $(32.5$ v. $36.6 \%)$ in the UK compared to the Canadian TV diet.

\section{Discussion}

\section{Summary of main results}

We compared food-related advertisements and the nutritional content of foods advertised during prime-time television in a single autumn week in Canada and the UK in 1991 and 2006. Whilst the proportion of all advertisements that were food-related decreased substantially between 1991 and 2006 in both countries, the frequency of food-related advertisements per programming hour was relatively constant in Canada but decreased between 1991 and 2006 in the UK. In 1991, advertisements for beverages and meals predominated in both countries. By 2006, food-related advertisements in Canada were dominated by meals and restaurants, whilst in the UK almost half of all food-related advertisements were for either food stores or beverages.

The advertised TV diet in Canada in 1991 could be described as relatively high in fat, high in alcohol and low in fibre, compared to current recommendations. By 2006, this had changed to high in fat and sodium and low in fibre (data on sodium was not available for Canada in 1991). The TV diet in the UK in 1991 was high in fat, sodium, sugar and alcohol and low in fibre compared to current recommendations. By 2006, all of these labels persisted, except for the high fat, leaving a TV diet that could be described as high in sodium, sugar and alcohol and low in fibre.

Some improvements were seen in the nutritional content of the TV diet between 1991 and 2006 in both countries with the percentage of energy derived from alcohol decreasing and the fibre density increasing in both countries. In addition, the percentage of energy derived from fat and the sodium content of the UK TV diet decreased over time. However, deterioration also took place with the percentage of energy derived from sugar increasing in both countries between 1991 and 2006.

\section{Explanation and interpretation of the findings in relation to the literature}

Most previous research on television food advertising has focused on children's television ${ }^{(16-20,25,26,28)}$. In contrast, we analysed prime-time television, when most viewing takes place. As in previous work, we found that the proportion of all advertisements that were for food-related products has decreased over time ${ }^{(39-41)}$. However, the 'big five' of commonly advertised foods on children's television, consisting 
of fast food, high-sugar soft drinks, salty snacks, high-sugar breakfast cereals, and confectionery $(5,15-19,25,26,28)$ was not predominant in our analyses.

The rising dominance of advertisements for meals and restaurants in Canada and food stores in the UK in 2006 may reflect changing social patterns in these countries. In the $\mathrm{UK}$, food retailing is increasingly dominated by four supermarket chains ${ }^{(54)}$, whilst British and Canadian adults now spend less that 45 minutes per day, on average, cooking and washing up ${ }^{(55,56)}$. It is possible that restaurants in the UK are less 'branded' (i.e. less likely to be chains) that those in Canada and so less able to purchase television advertising, but this is difficult to confirm without substantial further investigation. An increase in the proportion of food advertisements for restaurants over time has also been noted in US data ${ }^{(39)}$.

The growth in advertisements for food stores and restaurants between 1991 and 2006 may also reflect changing regulatory climates. New regulations on television food advertising to children came into force in the UK in April $2007^{(57)}$ whilst self-regulated advertising codes of practice were strengthened in Canada ${ }^{(58)}$. Both standards focus on food products only and do not cover advertisements for restaurants or food stores. It is possible that advertisers were already changing their pattern of marketing in late 2006 in anticipation of the introduction of these new regulations and in response to increasing lobbying from pressure groups ${ }^{(59)}$

Like recent findings from Australia ${ }^{(40,41)}$, we found some evidence of improvement in the nutritional quality of advertised foods over time. However, these were not universal and some deterioration also occurred. In addition to the 'high fat, salt, sugar' label often applied to foods advertised on children's television ${ }^{(60)}$, we would also add 'low fibre'. There is little evidence that television food advertising reflects a particularly healthful diet or even the healthfulness of the diets of individuals living in the UK and Canada.

\section{Limitations of the study}

We attempted to maintain a constant approach to data collection and analysis across all four data sets. However, we were necessarily limited by changes in technology and data availability over time and between Canada and the UK. We also attempted to replicate, as far as possible, the methods of a previous analysis based on data collected more than 15 years ago and this necessarily imposed limitations on our approach to the analysis of the more recent data.

As we have focused on only one week in 1991 and 2006, we were unable to study any seasonal variations in television food advertising and our results are not necessarily generalisable to other times of year. However, by using the same week in all cases, it is unlikely that such seasonal variations contribute to the differences reported here.

We restricted our analysis to prime-time television. Although relatively short in duration, prime-time routinely attracts the largest audiences and most attention from both programme makers and advertisers. Following changes in what commercial channels are available in both Ontario and the UK, the channels included in 1991 and 2006 are not identical. Whilst this may influence the mix of food-related advertisements included in our samples, it also reflects real-life changes in television viewed. Analyses restricted to only those channels that were available in both years led to very similar patterns of results to those reported here (data not shown). By restricting our analyses to free-to-view channels, the present results are not necessarily generalisable to all channels available. Furthermore, as digital, cable and satellite channels have proliferated in recent years, the 2006 data may be less generalisable across all channels available than the 1991 data.

The present data on what products were promoted came, in the main, from audience research bureaux. Given that these are commercial organisations who sell data to broadcasters, manufacturers and advertisers, the data they supplied are likely to be accurate. However, as we did not view the majority of advertisements, we had to rely on the audience research bureaux interpretation of what products were advertised. We were not, therefore, able to take into account incidental shots or mentions of other related products during advertisements. Neither did we include instances of programmes sponsored by food products or food product placement within programming.

The method of assigning nutritional data to advertised food products varied between 1991 (when computer software was used to assign values based on generic foods) and 2006 (where product-specific data was used as far as possible). Whilst the 2006 nutritional data are likely to be more product-specific than the 1991 data, there is no reason to believe that the 1991 data was biased in any particular direction.

Our use of 'default' products to represent the nutrient content of advertisements for brand ranges may have introduced some error. Although a very similar pattern of results to those reported here was found when using the mean nutrient content of all products in the brand ranges advertised (data not shown), the assumption that advertisements for brand ranges are comparable to advertisements for single products may be wrong. In particular, we did not elect a default product to represent advertisements for food stores and restaurants, which could also be considered to be marketing brands. As the new UK regulations only apply to product-specific advertisements, advertisements for brand ranges may become more common over time as a way to 'side-step' the regulations.

We used standard portion sizes to determine the weight or volume of advertised products that contributed to the overall 'TV diet'. This approach has been used in other analyses of television food advertising ${ }^{(22,23)}$. Whilst standard portion sizes may substantially underestimate the true weight of products that individuals consume, they appear to do this to a consistent degree meaning that relative nutritional composition of diets estimated by standard and actual portion sizes are highly correlated ${ }^{(61)}$. Our approach to quantifying the TV diet is, therefore, likely to represent a good estimation of the nutritional composition of eating one real-life portion of every food advertised. However, the concept of the TV diet is intended more as a method of summarising advertised products, rather than an indication of what television viewers are assumed to eat. Individuals are unlikely to consume a diet entirely guided by the advertisements they have watched and some advertisements may be more effective in encouraging consumption than others.

Finally, these analyses describe the food advertisements broadcast and provide no information on the effect of advertisements on actual behaviour. 


\section{Conclusions and future directions}

We have found that the proportion of all advertisements that were for food-related products decreased between 1991 and 2006 in both Canada and the UK. Whilst the frequency of food-related advertisements also decreased over time in the UK it stayed constant in Canada. This occurred alongside a fairly steady increase in the prevalence of overweight and obesity in the UK and Canada ${ }^{(62,63)}$. The 'big five' categories of food traditionally described as predominating in food advertising on children's television ${ }^{(5,15-19,25,26,28)}$ were not seen in our analyses. Although there were some indications that the nutritional content of the TV diet was healthier in 2006 compared to 1991 in both countries, the TV diet in 2006 remained consistently low in fibre and high in sodium in both countries, and also high in fat in Canada and high in sugar and alcohol in the UK. The present results suggest that whilst there are key differences between food-related advertising on television specifically targeted at children and those during more mainstream programming broadcast during prime-time, the overall story is the same: foods advertised on television do not reflect a healthful diet.

Alongside the substantial research available on television food advertising to children, it is important to also consider the effects of such advertising on adults. Despite adults' increased understanding of the aims and tricks of marketing, there may be good reason, in public health terms, for restricting all television food advertising.

Further research is required to document and assess the impact of food advertising in other television and non-television spheres. Alongside burgeoning numbers of commercial television channels, additional opportunities for advertising, such as mobile telephones and the Internet, have also developed over recent years. It will be important to document food advertising in these spheres as well as any differences in television food advertisements across different types of channels and according to whether programmes are watched as broadcast, following recording, or on on-line play-back services. The changes in television food advertising regulations in Canada, the UK, and other places, may increasingly push manufacturers and retailers into less regulated marketing spaces such as the Internet ${ }^{(64)}$.

During debates on food advertising, food manufacturers stress their right to make consumers aware of new products, broadcasters stress the importance of advertising to fund high-quality output, and adult consumers say that they often enjoy advertising for themselves (although not necessarily for their children) and object to government interference in everyday life ${ }^{(14,65,66)}$. There is clearly a difficult balance to be struck between public health concerns and the rights of industry, broadcasters and individuals ${ }^{(65)}$. Obesity is also a complex phenomenon. Whilst increasing regulation of television food advertising may play some role in preventing and reversing overweight and obesity in both children and adults, multi-pronged intervention strategies will be required to halt and reverse the obesity epidemic ${ }^{(67)}$.

\section{Acknowledgements}

The work described in this paper was performed at the Institute of Health and Society, Newcastle University, UK and the Department of Family Relations and Applied Nutrition, University of Guelph, Canada. This research was supported by the Medical Research Council (grant number G106/ 1253). The authors have no conflicts of interest to declare. T. Ø. led the original study of Canadian data in 1991 and M. W. contributed to it. J. A. and M. W. conceived the idea for the 2006 analysis. All authors contributed to study design. J. A. and K. H.-P. performed the data analysis. All authors contributed to data interpretation. J. A. drafted the manuscript. All authors commented on earlier drafts of the manuscript and approved the final version.

\section{References}

1. Beaglehole R, Irwin A \& Prentice T (2003) World Health Report 2003. Geneva: WHO.

2. Robinson TN (2001) Television viewing and childhood obesity. Pediatr Clin North Am 48, 1017-1025.

3. Caroli M, Argentieri L, Cardone M, et al. (2004) Role of television in childhood obesity prevention. Int J Obes 28, S104-S108.

4. Coon KA \& Tucker KL (2002) Television and children's consumption patterns: a review of the literature. Minerva Pediatr 54, 423-436.

5. Hastings G, Stead M, McDermott L, et al. (2003) Review of Research on the Effects of Food Promotion to Children. Final Report for the Food Standards Agency. Glasgow: Centre for Social Marketing.

6. Nestle M (2006) Food marketing and childhood obesity matter of policy. $N$ Engl J Med 354, 2527-2529.

7. Halford JCG (2005) Serving up trouble? Advertising food to children. Psychologist 5, 284-287.

8. WHO (2004) Global Strategy on Diet, Physical Activity and Health. Geneva: WHO.

9. Department of Health (2004) Choosing Health: Making Healthy Choices Easier. London: HMSO.

10. Public Health Association of Australia Inc. (2006) Television Food Advertising During Children's Viewing Times - Position Statement. Public Health Association of Australia. http:// www.phaa.net.au//documents/emailList/TVfoodAdvertPosStatement.pdf

11. Coalition on Food Advertising to Children (2007) Children's health or corporate wealth? The case for banning television food advertising to children. http://www.chdf.org.au/foodadstokids/

12. McGinnis JM, Goolman JA \& Kraak VI (editors) (2006) Food Marketing to Children and Youth: Threat or Opportunity? Washington, DC: The National Academies Press.

13. Anon (2003) The elephant in the room: evolution, behaviouralism, and counteradvertising in the coming war against obesity. Harv Law Rev 116, 1161-1184.

14. Ofcom (2004) Childhood Obesity - Food Advertising in Context: Children's Food Choices, Parents' Understanding and Influence, and the Role of Food Promotion. London: Ofcom.

15. Ostbye T, Pomerleau J, White M, et al. (1993) Food and nutrition in Canadian 'prime time' television commercials. Can $J$ Public Health 84, 370-374.

16. Chapman K, Nicholas P \& Supramaniam R (2006) How much food advertising is there on Australian television? Health Promot Int 21, 172-180.

17. Connor SM (2006) Food-related advertising on preschool television: building brand recognition in young viewers. Pediatrics 118, $1478-1485$

18. Lewis MK \& Hill AJ (1998) Food advertising on British children's television: a content analysis and experimental study with nine-year olds. Int J Obes Relat Metab Disord 22, $206-214$ 
19. Rodd HD \& Patel V (2005) Content analysis of children's television advertising in relation to dental health. Br Dent $J \mathbf{1 9 9}$, $710-712$

20. Chestnutt IG \& Ashraf FJ (2002) Television advertising of foodstuffs potentially detrimental to oral health - a content analysis and comparison of children's and primetime broadcasts. Community Dent Health 19, 86-89.

21. Dibb S \& Gordon S (2001) TV Dinners: What's Being Served Up by the Advertisers? London: Sustain: The Alliance for Better Food and Farming.

22. Powell LM, Szczypka G, Chaloupka FJ, et al. (2007) Nutritional content of television food advertisements seen by children and adolescents in the United States. Pediatrics 120, 576-583.

23. Harrison K \& Marske AL (2005) Nutritional content of foods advertised during the television programs children watch most. Am J Public Health 95, 1568-1574.

24. Dibb S \& Castell A (1995) Easy to Swallow, Hard to Stomach: The Results of a Survey of Food Advertising on Television. London: Sustain.

25. Hammond KM, Wyllie A \& Casswell S (1999) The extent and nature of televised food advertising to New Zealand children and adolescents. Aust N Z J Public Health 23, 49-55.

26. Kotz K \& Story M (1994) Food advertisements during children's Saturday morning television programming: are they consistent with dietary recommendations? J Am Diet Assoc 94, 1296-1300.

27. Østbye T, Pomerleau J, White M, et al. (1993) Food and nutrition in Canadian 'prime time' television commercials. Can J Public Health 84, 370-374.

28. Outley CW \& Taddese A (2006) A content analysis of health and physical activity messages marketed to African American children during after-school television programming. Arch Pediatr Adolesc Med 160, 432-435.

29. Byrd-Bredbenner C \& Grasso D (2000) Health, medicine, and food messages in television commercials during 1992 and 1998. J Sch Health 70, 61-65.

30. Lank NH, Vickery CE, Cotugna N, et al. (1992) Food commercials during television soap operas: what is the nutrition message? J Community Health 17, 377-384.

31. Story M \& Faulkner P (1990) The prime time diet: a content analysis of eating behavior and food messages in television program content and commercials. Am J Public Health 80, $738-740$.

32. Lobstein $\mathrm{T} \&$ Dibb S (2005) Evidence of a possible link between obesogenic food advertising and child overweight. Obes Rev 6, 203-208.

33. Canada House of Commons (2007) Competition Act. Official Report of Debates (Hansard) 141, 7747.

34. Legislative Assembly of Ontario (2008) Consumer Protection Amendment Act (Advertising Food or Drink). Official Report of Debates (Hansard) 22A, 760.

35. Centre for Science in the Public Interest (2004) Proposal for an Effective Integrated Pan-Canadian Healthy Living Strategy. Ottawa: Centre for Science in the Public Interest.

36. Ontario Medical Association (2005) An Ounce of Prevention or a Ton of Trouble: Is There an Obesity Epidemic in Children? A Position Statement. Toronto: Ontario Medical Association.

37. Heart and Stroke Foundation of Canada (2006) Overweight, Obesity, and Heart Disease and Stroke: A Position Statement. Ottawa: Heart and Stroke Foundation of Canada.

38. Hawkes C (2005) Self-regulation of food advertising: what it can, could and cannot do to discourage unhealthy eating habits among children. Nutr Bull 30, 374-382.

39. Byrd-Bredbenner C \& Grasso D (2000) Trends in US primetime television food advertising across three decades. Nutr Food Sci 30, 59-66.
40. Hattersley L, Kelly B \& King L (2007) Food Advertising on Sydney Commercial Television: Five Year Trends in the Extent and Nature of Children's Exposure. Sydney: NSW Centre for Overweight \& Obesity.

41. Kelly B, Smith B, King L, et al. (2007) Television food advertising to children: the extent and nature of exposure. Public Health Nutr 10, 1234-1240.

42. British Audience Research Board (2008) TV facts. www.barb.co.uk/tvfacts.cfm?fullstory=true\&includepage $=$ share $\&$ flag $=$ tvfacts (accessed April 2008).

43. Health Canada (1990) Action Toward Healthy Eating ... Canada's Guidelines for Healthy Eating and Recommended Strategies for Implementation. Report of the Communications/Implementation Committee. Ottawa: Ministry of Supply and Services.

44. Health Canada (1990) Nutrition Recommendations. The Report of the Scientific Review Committee. Ottawa: Ministry of Supply and Services.

45. Food Standards Agency (2002) McCance and Widdowson's The Composition of Foods, 6th ed. Cambridge: Royal Society of Chemistry.

46. Health Canada (2008) Canadian Nutrient File: compilation of Canadian Food Composition Data. http://www.hc-sc.gc.ca/fnan/ nutrition/fiche-nutri-data/index_e.html (accessed February 2008).

47. Pennington JAT (1989) Bowes and Church's Food Values of Portions Commonly Used, 15th ed. Philadelphia: J.B. Lippincott Company.

48. Statistics Canada (2004) Food Statistics, vol. 4 no. 1. Ottawa: Statistics Canada.

49. Health Canada (2007) Canadian Community Health Survey, vol. 1. Ottawa: Ministry of Supply and Services Canada.

50. Henderson L, Gregory J \& Swan G (2002) The National Diet and Nutrition Survey: Adults Aged 19 to 64 Years. London: Office for National Statistics.

51. Department of Health (1991) Dietary Reference Values for Food Energy and Nutrients for the United Kingdom. Report on Health and Social Subjects no. 41. London: HMSO.

52. Institute of Medicine of the National Academies (2002) Dietary Reference Intakes for Energy, Carbohydrate, Fiber, Fat, Fatty Acids, Cholesterol, Protein, and Amino Acids. Washington, DC: The National Academies Press.

53. Institute of Medicine of the National Academies (2004) Dietary Reference Intakes for Water, Potassium, Sodium, Chloride, and Sulfate. Washington, DC: The National Academies Press.

54. Garner E (2008) Grocery market share information. http:// www.retail-week.com/images/TNSGro52WkroFeb24_tcm14-85 7677.pdf (accessed February 2008).

55. Minister of Industry (2006) Overview of the Time Use of Canadians, 2005. Ottawa: Minister of Industry.

56. Lader D \& Meltzer H (2003) Smoking Related Behaviours and Attitudes, 2002. London: Office of National Statistics.

57. Rayner M, Scarborough P, Boxer A, et al. (2005) Nutrient Profiles: Development of Final Model. Final Report for the Food Standards Agency. Oxford: British Heart Foundation Health Promotion Research Group, Department of Public Health, University of Oxford.

58. Advertising Standard Canada (2008) Self-regulation of children's Advertising in Canada. http://www.adstandards.com/en/ childrensinitiative/selfRegulation.html (accessed April 2008).

59. The Consumers' Association (2006) Which? Food Fables: Exploding Industry Myths on Responsible Food Marketing to Kids. London: The Consumers' Association.

60. Ofcom (2007) Television Advertising of Food and Drink Products to Children - Final Statement. London: Ofcom.

61. Welten DC, Carpenter RA, McPherson RS, et al. (2000) Comparison of a dietary record using reported portion size versus 
standard portion size for assessing nutrient intake. Public Health Nutr 3, 151-158.

62. Katzmarzyk PT \& Mason C (2006) Prevalence of class I, II and III obesity in Canada. CMAJ 174, 156.

63. Craig R \& Mindell J (2008) Health Survey for England, 2006, Latest Trends. London: The Information Centre.

64. Linn S \& Novosat CL (2008) Calories for sale: food marketing to children in the twenty-first century. Ann Am Acad Pol Soc Sci 615, 133-155.
65. Caraher M, Landon J \& Dalmeny K (2006) Television advertising and children: lessons from policy development. Public Health Nutr 9, 596-605.

66. Graff SK (2008) First amendment implications of restricting food and beverage marketing in schools. Ann Am Acad Pol Soc Sci 615, 158-177.

67. Butland B, Jebb S, Kopelman P, et al. (2007) Foresight Tackling Obesities: Future Choices - Project Report. London: Government Office for Science. 